\title{
Olistostrome and the mesozoic tectonic of the bantimala complex, South Sulawesi
}

\author{
Kaharuddin $\mathrm{MS}^{1 *}$, A.M. Imran ${ }^{1}$, Chalid Idham Abdullah², and Asri Jaya ${ }^{1}$ \\ ${ }^{1}$ Geology Engineering Department Faculty of Engineering, Hasanuddin University, 90245 Makassar, Indonesia \\ ${ }^{2}$ Geology Engineering Department Faculty of Earth Science and Technology, Bandung Institute of Technology, 40116 \\ Bandung, Indonesia
}

\begin{abstract}
The study aims to determine the presences and spreads of the olistostrome as one components of the tectonic complex of Bantimala area. The basement rocks of Bantimala area is a metamorphic rocks, which are unconformably overlain by Balangbaru Formation and radiolarian chert. Beneath in between cherts and basement rocks are presence breccia schists which give rise to various presumptions and interpretations of the environment and conditions of formation as submarine deposit, ideally cherts in the area underlain by oceanic crust. Schist breccias presence underneath of cherts in the Bantimala Complexes were suggested an olistostrome deposit. It was characterized by poorly sorting, unfoliated, shows deformed textures and composed olisthtolits which are embedded in sandy matrices, and in the cherts are presence layer sandstones and schist fragments. Olistostrome is sedimentary deposit as preserved in the trench, they will give us an interpretation that prior to formed cherts in the Bantimala area, initially tectonic subduction activity which are deforming and brecciation of the basement rocks subsequently as the constituent material of olistostrome.
\end{abstract}

\section{Introduction}

The olistostrome of Bantimala Tectonic Complexes is likely related to Western Pacific plate has subducted to Asian Continent during Mesozoic, the interaction both of the plates were caused deformation, metamorphism and olistotrome deposits. These situation is reasonably allow to occur a debris fall due to steep slope in the part of trenches as suggested by [1], [2], their fragments possibly are eroded debris materials from continent and oceanic plates, they have been mixed as a chaotic sedimentary deposits, its immediately covered by deep marine sediments of radiolarian cherts.

The oldest rocks were exposed in the Bantimala Complexes are Triassic metamorphic rocks composed of glaukofan schists, mica-hornblende schists, eclogites, granulits, quartz phyllite and quartzite [3]. On the top of this basement rocks is overlain by breccias, schists (olistostrome), sandstones and radiolarian cherts indicating Jurassic - Cretaceous age [4].

Our side observations that schist breccias in the study area is an olistostrome deposits characterized by present vary of olistolith schists, stratigraphically it overlain by radiolarian cherts. So far, the study of olistotrome in the area has never been studied, but previous studies it was indicated a mélange [5] thought a chaotic sedimentary processing which is more appropriately considered as olistostrome.

\section{Methods}

This study emphasizes field observations and petrographic analysis. Field observations was performed stratigraphic detail by measuring section and cross section along Patteteyang river, observing the relationship between the lithologic unit and indication deformation structures in the field and rocks sampling. Further observations were made followed by petrographic analysis to determine the texture and rock composition for all components of rocks, especially for olistolith and matrices.

\section{Regional geology and tectonic setting}

Tectonically the Bantimala Complexes is still contentious, including presence of rocks faragments and interrelationship each other such as presence of mélanges, schist basement rocks, rocks continent affinity, radiolarian cherts and Paleogene volcanics.

\subsection{Geological setting}

The basement rocks were exposed in the Bantimala area is part of shelf margin of East Kalimantan which was separated since Miocene coincided with the occurrence of Makassar Strait. The basement rocks is called the Bantimala Tectonic Complex where composed of: Triassic metamorphic rocks namely glaucophane schists,

* Corresponding author: kaharuddin_geounhas@yahoo.com 
hornblende-mica schists, eclogites, granulites, phyllitesand metaquarzites [3]; Jurassic-Cretaceous of mélange composed of quartz schists, metacherts, metabasalts. Cretaceous sedimentary rocks which composed of fine-siliceous shales, sanstone, mudstone and radiolarian cherts.

Ophiolite blocks consisting of harzburgites and serpentinites where occur through out tectonic obduction which covered or structural contact with the Tertiary rocks in the area, whereas sedimentary type of continental shelf margin are Cretaceous of typical flysch sedimentary rocks of Balangbaru-Paremba Formations. They were unconformity overlain by quartz sandstones of Mallawa Formation and Paleocene-Eocene volcanics. They are covered by Eocene-Miocene limestone of Tonasa Formation and Upper Miocene-Pliocene breccias and tuffs of Camba Formation [6] Fig 1.

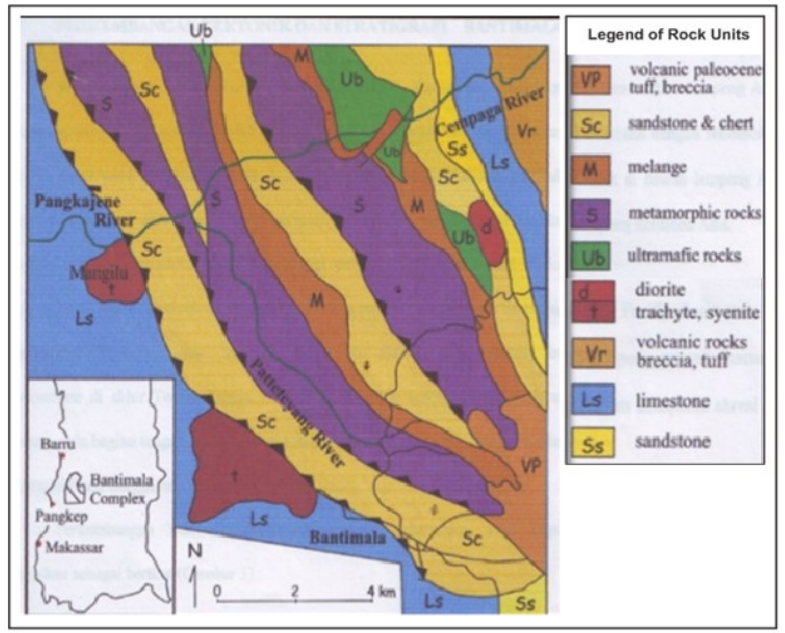

Fig. 1. Geological map of Bantimala area (modified from Sukamto, 1986).

\subsection{Tectonic setting}

The Bantimala Complex is formed in two tectonics phases, the first is subduction system of oceanic plate that took place during the Mesozoic to Tertiary. The second is ophiolite obduction system that took place during Tertiary to Quaternary. The presence of high grade of metamorphic rocks associated with system during preCretaceous (Triassic - Jurassic), it may cause by the West Pacific plate subducted to the East Kalimantan continent, which was produced accretion complex on the eastern shelf of Asian Continental plates. During Jurassic to Cretaceous the accretion complex has deformed to produce a mélange rocks [7-8]. During the Early Cretaceous occurred brecciation in the accretion complexes formed breccia - schist [5] or here called olisostrome [9], while continuing deposited chert and contemporaneously with deposition in the trench of terrigenic sediment of Balangbaru (Figure 2).

More over the Cretaceous of Bantimala Complexes have been situated by some of previous study such as [10] and [11], according to them that the establishment of a high-pressure metamorphic rocks associated low-grade metamorphic rocks, mélange and ultramafic in this region are the results of system subduction of oceanic crust into the shelf margin of continental plates in the Jurassic to the
Early Cretaceous (114 to $132 \mathrm{Ma}$ ). Based on calculations of pressure - temperature of rocks garnet glaucophaneresulted a temperature of $580-640{ }^{\circ} \mathrm{C}$ and pressures 18-24 kbar, occurs at depth 65-85 km [5]. Furthermorethe breccia of Bantimala Complexis unconformably overlain by the Radiolarian chert which ranging from Albian to Cenomanian in age ( $\pm 100 \mathrm{Ma})$ [12].

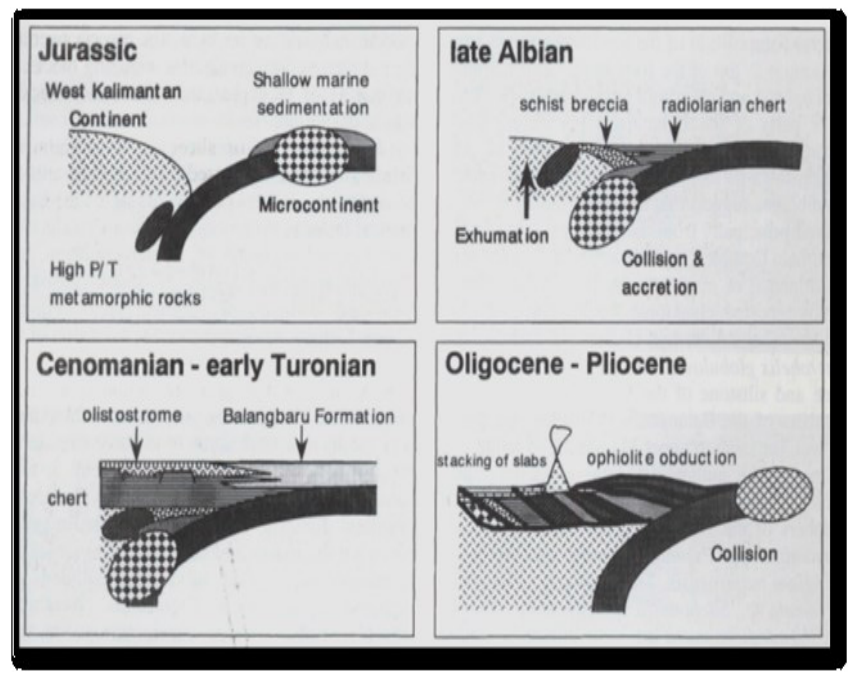

Fig. 2. Progressive of tectonic evolution of Bantimala Complex, during Mesozoic to Tertiary (Wakita et al., 1996)

\section{Physical properties of Olistostrome}

Lithologic characterized of olistostrome of Bantimala Complex could be described into two aspects i.e. based on components and sedimentary types.

\subsection{Component Fabrics}

Olistostrome component in the Bantimala Complex shows various clast of material component swhich is indicated difference origin (polymictic), it composed by deformed and reworked materials derived from subduction activity which consisting of schist, quartzite and gneiss, serpentinite, metachert, the components are vary in grain size ranging from centimeter to several meter, poorly sorting and angular to subangular. Fragments floating in reddish chert matrices suggesting retransported material within a trench, deformed textures indicated by lenses, fracturing, shows pseudofoliation with slipped surface (Figure 9 and 10).

The following is results of petrographic analysis of olistoliths of olistostrome, schists, cherts, and sandstoneas follows:

1. Schists and Quartzite Olistoliths:

- Schist olistoliths of schist muscovite quartz (OL, 5C), lepidoblastic textures, composed by muscovite $40 \%$, quartz $30 \%$, chlorite $20 \%$, actinolite $5 \%$, mineral opak 5\% (Fig. 3).

- Quartzite Olistolith (OL, 5D), composed byquartz $75 \%$, muscovite $12 \%$, and biotite $10 \%$, mineral opak $3 \%$, granoblastic textures (Figure 4). 


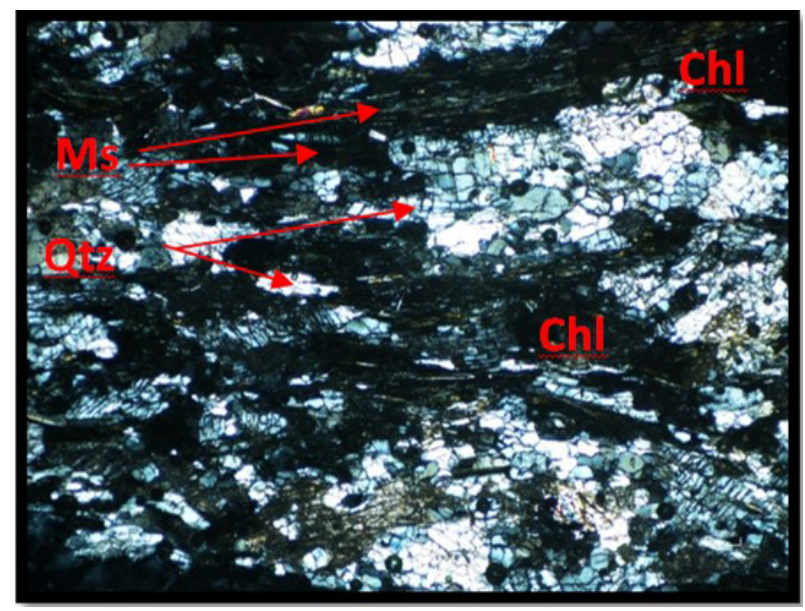

Fig. 3. Petrographic photo of muscovite schist $(\mathrm{Qtz}=\mathrm{Quartz}$; $\mathrm{Chl}=$ Chlorite $; \mathrm{Ms}=$ Muscovite)

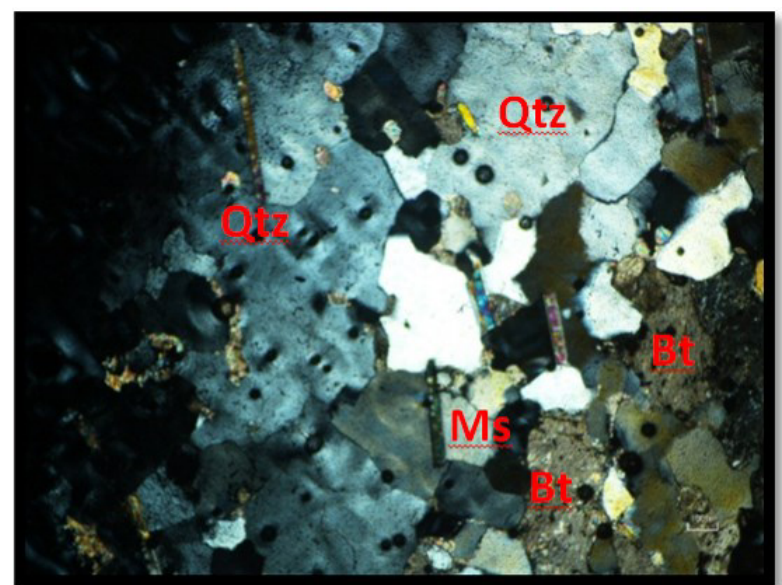

Fig. 4. Petrographic photo of quartzite $(\mathrm{Qtz}=\mathrm{Quartz} ; \mathrm{Bt}=$ Biotite $; \mathrm{Ms}=$ Muscovite)

2. Schist and greenschist

- Olistolith schist (OL, 2B), lepidoblastic textures composed by muscovite $65 \%$, quartz $20 \%$, chlorite $5 \%$, albite $6 \%$, and ore mineral $4 \%$ (Fig. 5 ).

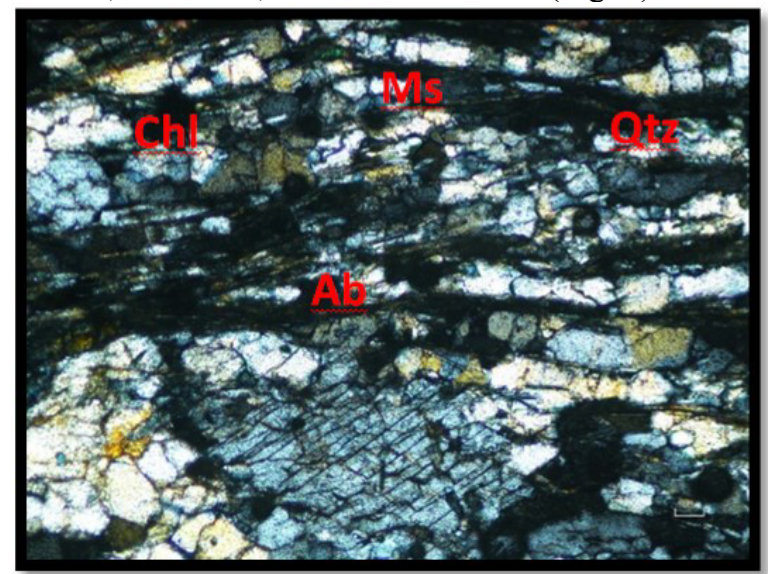

Fig. 5. Petrographic photo of olistolith schist $(\mathrm{Qtz}=\mathrm{Quartz} ; \mathrm{Ab}$ $=$ Albite $; \mathrm{Chl}=$ Chlorite Ms $=$ Muscovite $)$

- Green schist/ actinolite schist (ML, 3B), lepidoblastic textures, composed by actinolite $90 \%$, quartz $5 \%$, chlorite 3\%, ore mineral (Fig. 6).

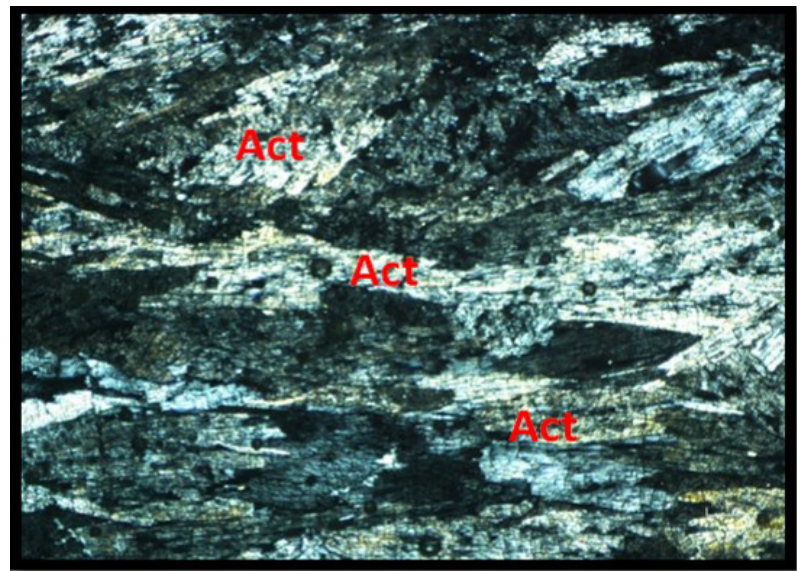

Fig. 6. Petrographic photo of actinolite schist $($ Act $=$ Actinolite $)$

3. Chert (C, 4E)

Chert composed by radiolaria $40 \%$, quartz $56 \%$, ore mineral 4\%, (Fig. 7).

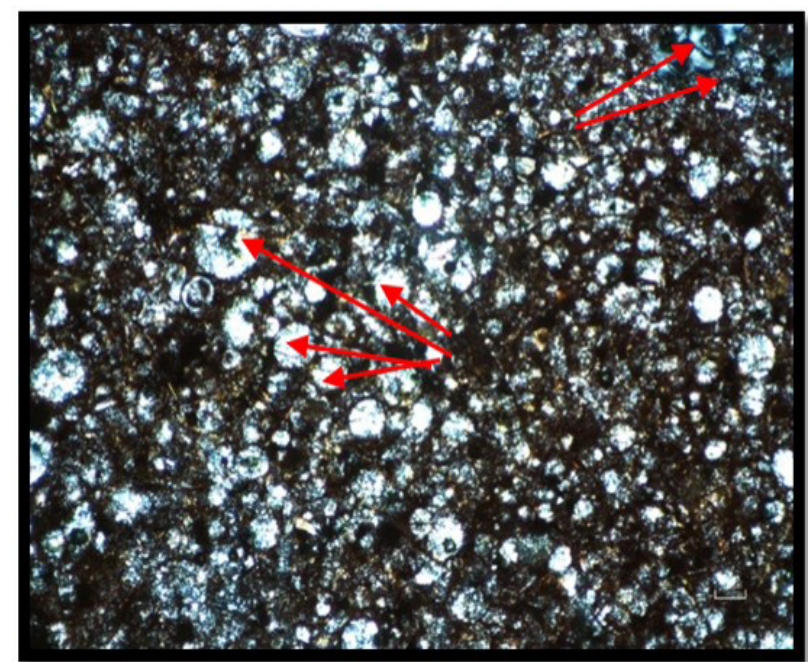

Fig. 7. Petrographic photo of chert (Rfs = Radiolarian Fossil ; Qzt $=$ Quartz)

4 Sandstone (ST. 13A)

Sandstone composed by muscovite $70 \%$, quartz $25 \%$, ore mineral 5\%, (Fig. 8 ).

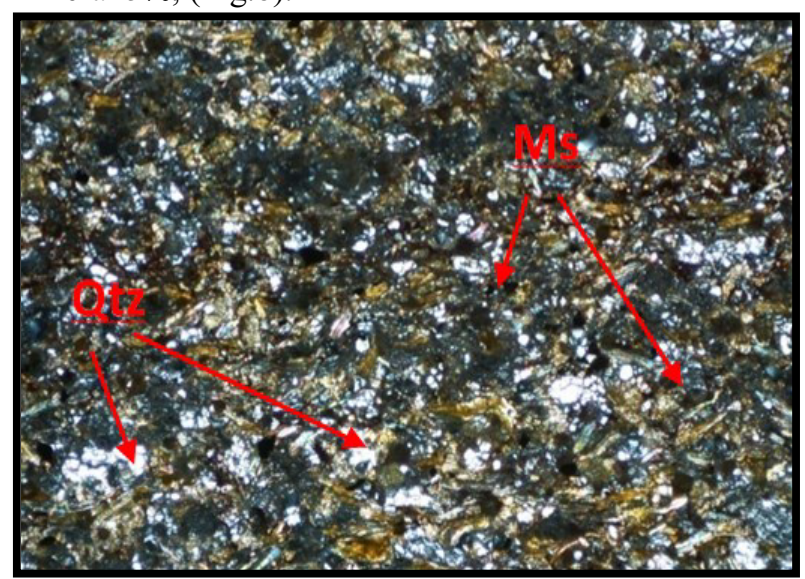

Fig. 8. Petrographic photo of actinolite schist $($ Act $=$ Actinolite $)$ 


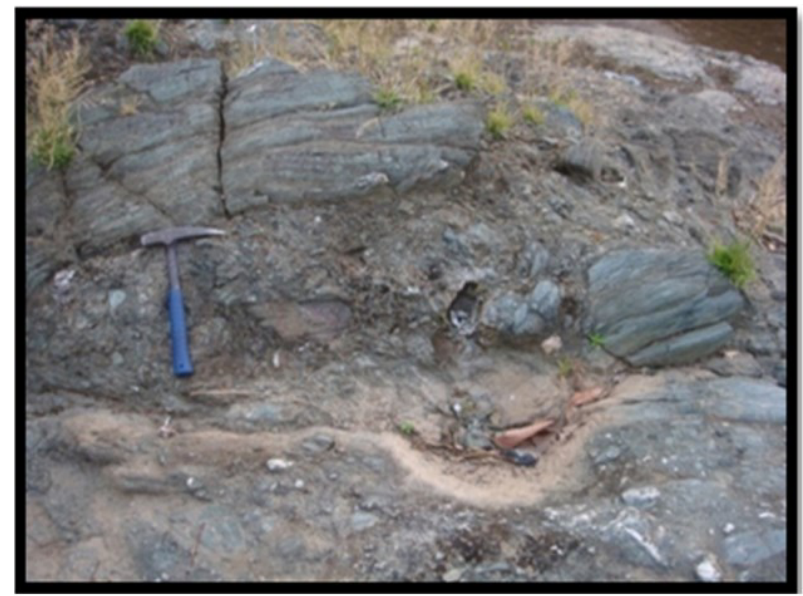

Fig. 9. Outcrop of olistostrome (fluxo) with tectonit textures, schist olistolith floating on matrices, Pateteyang River, Bantimala.

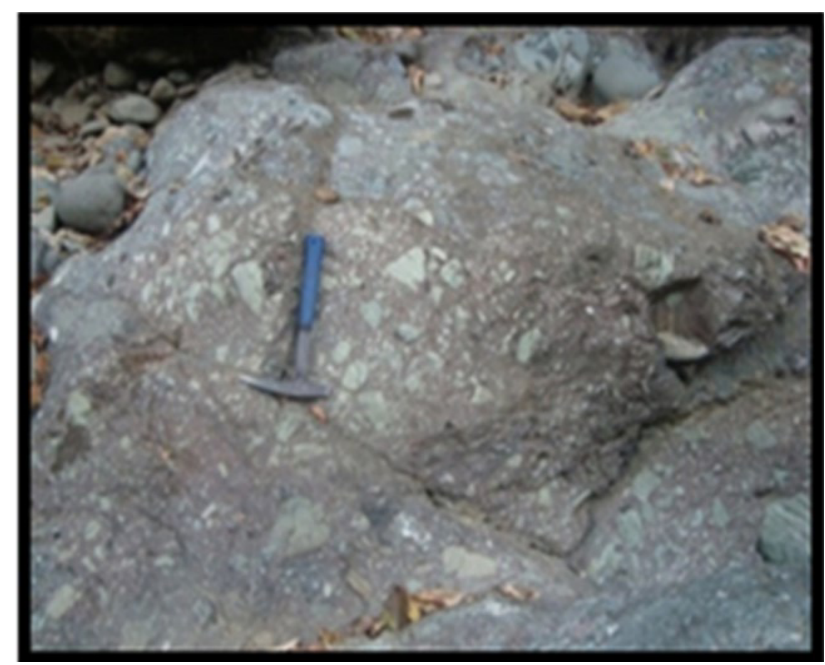

Fig. 10. Outcrop of olistostrome in the eastern part are show proxima deposit, Pateteyang River, Bantimala.

\subsection{Type and physiography sediment}

\subsubsection{Deposition type Olistostrome}

Quartz muscovite schist in one complex with glaucophane schists, granulits, eclogites and radiolarian cherts, as an indication of sediment avalanche or slope slumping at a relatively steep slope suggested rocks that preserve from subduction between the continental plates with oceanic plates, where olistostrome interbedded in part the bottom of the radiolarian cherts [13]. To mixing materials in chert clast and fining upwards structures, cobble - granule in grain sizes, indicating that they were preserve in a deep marine or trenches on subducting tectonic conditions, based on the above determination so that the olistostrome of Bantimala Complex is categorized as subduction type.

\subsubsection{Sediment Physiography}

The appearance of interbedded between the sandstones and radiolarian chert as the top of the olistostrome, gradational structure components in the western part of the study area including fluxo deposit. Based on deposit type in the eastern part and the contact between the radiolarian chert coarse grainsof olistolith indicated proksima type deposit (Fig. 9 and 10). Based on the spread and characteristics of layering can be interpreted the depositional direction of olistostrome from west to east. The presence of serpentinite - jadeite blocks of as exotic block in olistostrome is separate phenomenon to be determine in the future work. Body of olistostrome in Bantimala Complex suggested as a lensis in radiolarian cherts unit.

\section{The occurrences of olistotrome}

The process of subduction of the Pacific plate along continental margin of Kalimantan during Jurassic, initially the process of forming olistostrome of Bantimala. During that period waspreserved tectonic deformation, brecciation and metamorphism of the two plates subducted each other, which is accompanied by the formation of deep trenches as the depositional environment. Plate continental and oceanic plates that have undergone at low grade metamorphism and brecciated forming blocks as olistoliths that shows deformation textures.

Based on experiments [14] and [15] on the slopes of the critical condition allow submarine landslide occurred in the trench, the material falling as debris flow or slumping and widespread deposited on the ocean floor which its mixture with clast of continental and oceanic components, [16] and [17], (Fig. 11).

Based on their appearance in the field, olistostrome layer at Pateteyang River (Bantimurung Village), there are at least four cycle of avalanche or debris deposition of material inter bedded with cherts, namely:

- The first is preserve debris avalanches and slumping, forming as rock blocks with a thickness of $\pm 340 \mathrm{~m}$ olistolith sizes between 1-150 cm, angular and boudinage. Components consist of chlorite schist, mica schist, amphibolite schist, and quartzite gneiss.

- The second, before the second deposition is preceded by the deposition of a thin layer chertsof $20 \mathrm{~cm}$ thick and mixed with coarse grains of schist material followa debris avalanche of gravel-blockof schist clasts $(2-40 \mathrm{~cm})$, relatively smoother than the first avalanche, with a thickness $\pm 150 \mathrm{~cm}$.

- The third is also inter bedded by chert layers $60 \mathrm{~cm}$ in thick. The third layer is composed of schist clast with $25 \mathrm{~cm}$ thick.

- The fourth, deposition above of layer chert $(120 \mathrm{~cm}$ thick), a thin layer of schist clast $\pm 20 \mathrm{~cm}$ thick and 
covered by layers cherts that show the body olistostrome of Bantimala (Fig. 12). The composition and structure of the sediment grain size olistostrome shows fining upwards as debris flow sediment or turbidity (Table 1).

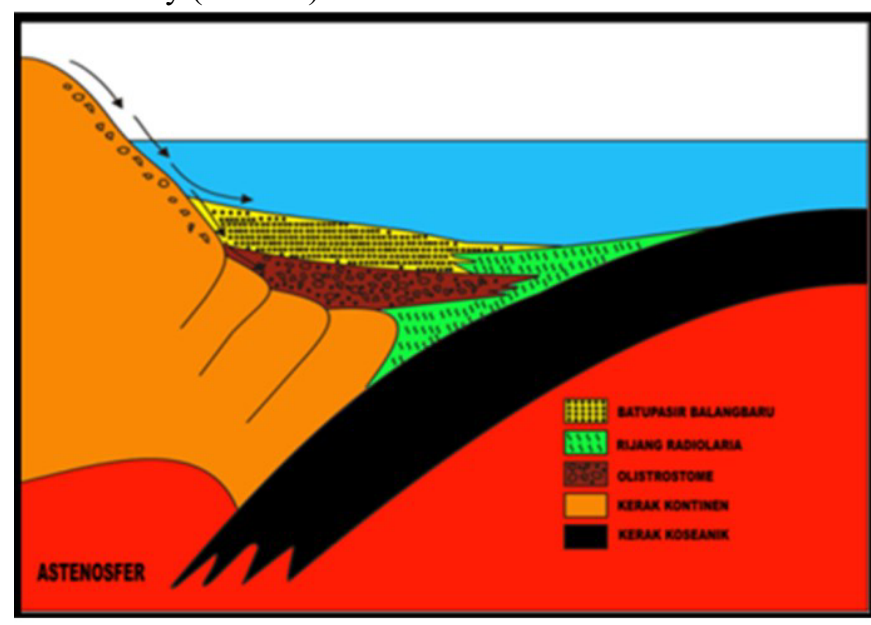

Fig. 11. Cross section of formation of olistotrome of Bantimala Complex, subduksi lempeng Oceanic Pasific plate (black) subducted to Asean Continental plate (orange) during Early Cretaceous.

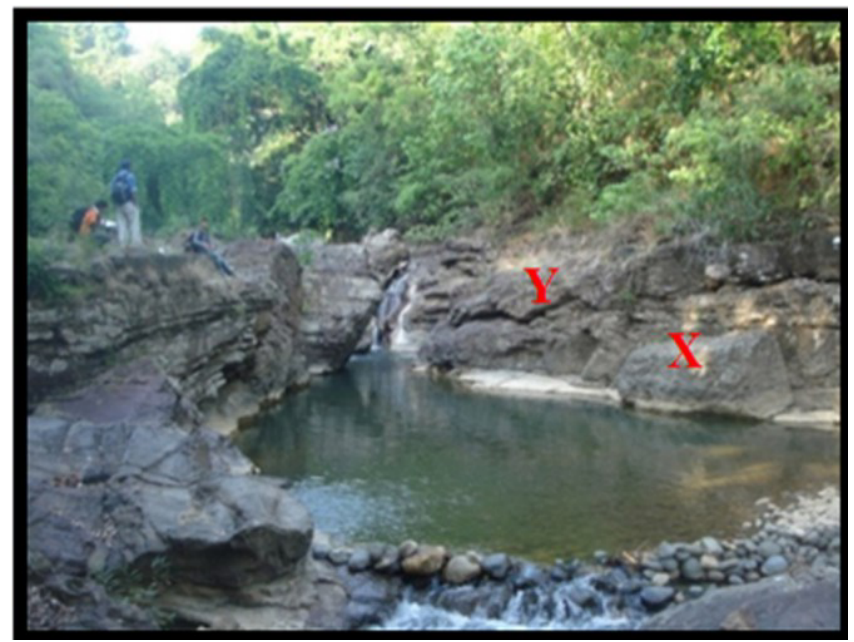

Fig. 12. Outcop olistostrome $(\mathrm{X})$ with radiolarian chert $(\mathrm{Y})$ in the Pateteyang River, Bantimala

\section{Discussion}

Synsedimentary deformation and tectonic implications, field data shows deformation of soft-sediment on cherts with showing small folds (antiform and synform) (Fig. 13), brecciation, dragfold, microthust, boudinage olistolith surrounded by a fine grained schist matrix, slump fold and slump ball (Fig. 14), indicated that during sedimentation contemporaneous with active tectonic condition.

The stratigrphy position of olistostrome by Wakita et al. (1996) is above the wedge with Radiolarian chert and intercalated with Balangbaru sandstone, and there are also schists interbedded chert on the bottom. Breccia schist by Wakita et al. (1996) and the authors include as olistostrome deposit. Stratigraphy position hardly visible in the field but by outcroping thin layer of $\pm 50 \mathrm{~cm}$ (Figure 10) olistostrome interbedded in chert in the eastern part of the area of research, it can be interpreted that the (1996) that is deposited in the same time with the slump sedimentation system on the bottom layer of chert.

\begin{tabular}{|c|c|c|}
\hline $\begin{array}{l}\text { Thicknesses } \\
\text { (cm) }\end{array}$ & $\begin{array}{c}\text { Lithologic } \\
\text { Units }\end{array}$ & Description \\
\hline$>1000$ & & Folded Radularian Chert \\
\hline 20 & $\vdots \vdots \vdots \vdots \vdots \vdots$ & Reddy Sandstone (4) \\
\hline 120 & & $\begin{array}{c}\text { Folded Chert } \\
\text { (antiform and sinform) }\end{array}$ \\
\hline 25 & $\vdots \vdots \vdots \vdots \vdots: \vdots$ & Coarse Sandstone (3) \\
\hline 60 & & Folded Radularian Chert \\
\hline 150 & 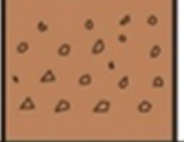 & $\begin{array}{c}\text { Polylitic Breccia (2), } \\
\text { Gradation Structure } \\
\text { Components : Schist, Quartzite, } \\
\text { Metachert }\end{array}$ \\
\hline 20 & & Schist Clasts In chert \\
\hline$>5000$ & $\left|\begin{array}{ccc}\Delta & \Delta & \Delta \\
0 & \Delta & 0 \\
0 & \Delta & 0 \\
0 & 0 & 0\end{array}\right|$ & $\begin{array}{c}\text { Polylitic Breccia (1), Chaotic } \\
\text { \& Proorly Sorted } \\
\text { Components : Schist, Quartzite, } \\
\text { Metachert, Gneiss }\end{array}$ \\
\hline & hMMAN & \\
\hline
\end{tabular}

Fig. 13. Tabel of stratigraphic column of olisostrom in Bantimala Complex

The stratigraphy relationship breccia schist in this case olistostrome is unconformable overlaying cherts (Wakita, et al., 1994), conversely based on the age of the fossil in radiolarian chert, breccia or sandstone is conformable. It is also supported by the appearance of the field that showed gradational from bottom-top with fining upward structures and almost breccias composed by schist clast indicated same environment and sedimentary sources suggested that the relationship between radiolarian chert and breccia schists is conformable.

\section{Conclusion}

a. Geological conditions and tectonic Bantimala Complex composed by pre-Tertiary components (Schists, olistostromes, radiolarian cherts and sandstones of Balangbaru Formation) and Tertiary components (Volcanic Paleocene, sandstones of Mallawa Formation, limestones of Tonasa Formation, Camba volcanic and basic-intermedite-acid igneous intrusions. Some of them bounded by thrust faults.

b. Characteristics of olistostrome in the Bantimala Coplex domostrated by heterogeneous components with polymictic breccias consisting of schist, gneiss, 
quartzite and metachert components, composed of three layers, namely breccia polymictic, coarse sand granule and sand. They including in olistostrome subduction type that formed in Lower Cretaceous (Albian).

c. Stratigraphycally the position of olistostrome or breccia schist conformably overlaying bv radiolarian chert.

d. The olistostrome component is characterized by deformation textures and interrelationship with radiolarian chert where it was deformed during of post-sedimentation of the Jurassic - Cretaceous.

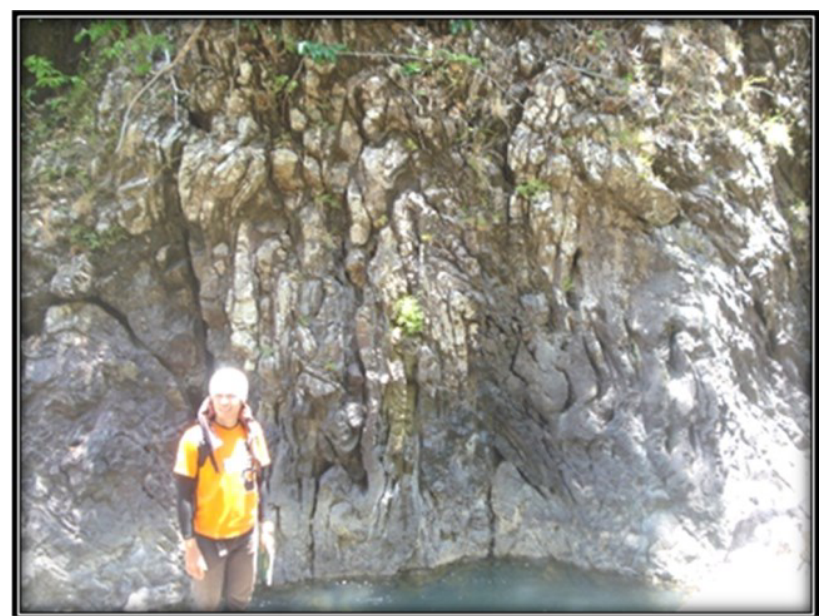

Fig. 14. Antiform $(\mathrm{X})$ and synform $(\mathrm{Y})$ structures in the cherts, Pateteyang River, Bantimala

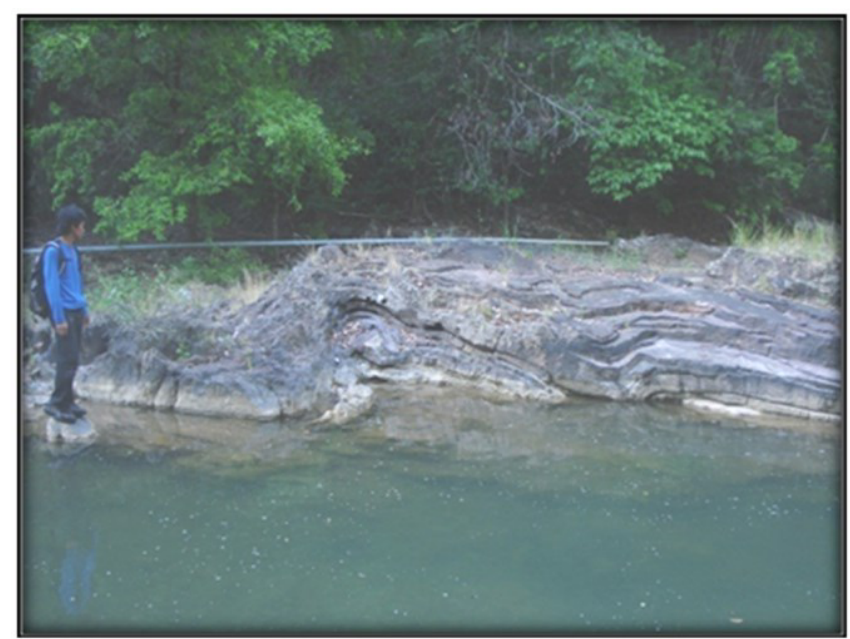

Fig. 15. Outcrop of radiolarian cherts deformed, Pateteyang River, Bantimala.

\section{References}

1. Hall, R., Ophiolite Emplacement and the Evolution of the Taurus Suture Zone, Suthern Turkey, The Geological Society of America, Benchmark Paper in Geology/66, p. 275 - 285 (1976)

2. Abbate, E., Bortolotti, V., Passerini, P., , Olistostromes and Olistoliths, Benchmark Papers in Geology/66, pp.86 - 110 (1970)
3. Sukamto, The Structure of Sulawesi in the Light of Plate Tectonics, Proceeding Regional Conferention Geology Mineral Resources SE Asia (1975)

4. Sukamto, R., Geologi Lembar Pangkajene dan Watampone Bagian Barat, Sulawesi, P3G, Departemen Pertambangan dan Energi Bandung (1982)

5. Wakita, K., Sopaheluwakan, J., Miyazaki, K., Zulkarnaen, I., Munasri, Tectonic of the Bantimala Complex, South Sulawesi, Indonesia, Tectonic Evolution of Southeast Asia, London (1996)

6. Sukamto, Tektonik Sulawesi Selatan dengan awan Khusus, ciri-ciri himpunan batuan daerah Bantimala, Disertasi S3 ITB, Bandung, 363p, unpublished (1986)

7. Kaharuddin, M., Geotectonic of the Sulawesi Region, Toyama University, Japan (1995)

8. Kaharuddin, Perkembangan Tektonik dan Stratigrafi Kompleks Bantimala, Sulawesi Selatan, Prosiding Hasil Penelitian Fakultas Teknik Unhas, vol.4, hal.TG 5-1-TG5-9 (2010)

9. Kaharuddin, Jaya, A., Sirajuddin, H., 2015, Olistostrome dan Batu Mulia Kompleks Tektonik Bantimala Kabupaten Pangkajene dan Kepulauan, Prosiding TPT XXIV dan Kongres IX Perhapi, Jakarta (2015)

10. Zulkarnain, I., Cretaceous Tectonic Events of the Bantimala Area, South Sulawesi - Indonesia : Evidence from Rock Chemistry, Jurnal Teknologi Mineral No. 2 - Vol. VI (1999)

11. Maulana, A., Mamma, K., Imai, A., Petrological Characteristic and Metamorphic Evolution of the Bantimala Complex, South Sulawesi Indonesia (2010)

12. Wakita, K., Munasri, Sopaheluwakan, J., Zulkarnain, I., Miyazaki, K., Early Cretaceous Tectonic Events Implied in the Time - log Between the Age of Radiolarian Chert and its Metamorphic Basement in Bantimala Area, South Sulawesi, Indonesia, Research Article, Bandung, Indonesia (1994)

13. Shuib, M.K., The Olistostrome in the Bentong Area, Pahang and their Tectonic Implications, Department of Geology, University of Malaya, Kuala Lumpur, Malaya (2000)

14. Yamada, Y., Yamashita, Y., Yamamoto, Y., Submarine Landslide at Subduction Margins : Insights From Physical Models, Tectonophysics, Elsevier (2009)

15. Festa, A., Pini, G.A., Dilek, Y., Codegone, G., Melanges and Melange-forming Processes : A Historical and New Concepts, International Geology Review, Vol. 52, Nos. 10 - 12, October - December 2010, 1040 - 1105 (2010)

16. Elter, P., Trevisan, L., Olistostromes in the Tectonic Evolution of the Northern Apennines, Benchmark Papers in Geology/66, pp.111 - 124 (1973)

17 Leonov, M.G., Olistostromes and their Origin, Benchmark Papers in Geology/66, pp.125-134 (1978) 